\title{
SOL-GEL SYNTHESIS AND XPS CHARACTERIZATION OF VANADIUM OXIDE BRONZES *
}

\author{
V. Bondarenka ${ }^{\text {a }}$, S. Grebinskij ${ }^{\text {a }}$, Z. Martūnas ${ }^{\text {a }}$, S. Mickevičius ${ }^{\text {a }}$, H. Tvardauskas ${ }^{\text {a }}$, \\ S. Kačiulis ${ }^{\mathrm{b}}$, L. Pandolfi ${ }^{\mathrm{b}}$, V. Volkov ${ }^{\mathrm{c}}$, and N. Podvalnaia ${ }^{\mathrm{c}}$

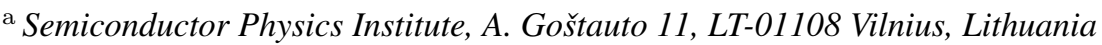 \\ E-mail: bond@pfi.lt \\ ${ }^{\mathrm{b}}$ Institute for the Study of Nanostructured Materials (ISMN-CNR), P. O. Box 10, I-00016 Monterotondo Staz (RM), Italy \\ ${ }^{\mathrm{c}}$ Institute of Solid State Chemistry, Pervomaiskaya 91, 620219 Yekaterinburg, Russia
}

Received 2 December 2005

\begin{abstract}
The results of synthesis of the vanadium oxide bronzes $\mathrm{NaV}_{2} \mathrm{O}_{5}, \mathrm{~K}_{4.3} \mathrm{~V}_{6} \mathrm{O}_{16.2}$, and $\mathrm{Rb}_{4.4} \mathrm{~V}_{6} \mathrm{O}_{16.1}$ are presented. The synthesis process can be described by three steps: the 1st - production of the sol by dissolving the necessary materials in $\mathrm{H}_{2} \mathrm{O}_{2}$ solution, the $2 \mathrm{nd}$ - fabrication of the gel by heating up to $350 \mathrm{~K}$, and the $3 \mathrm{rd}$ - heating up to $580-780 \mathrm{~K}$ for the water removal from the gel. The chemical composition of obtained bronzes was examined by using X-ray photoelectron spectroscopy (XPS) method.
\end{abstract}

Keywords: vanadium oxides, bronzes, sol-gel, XPS

PACS: $68.47 \mathrm{Gh}, 81.20 \mathrm{Fw}, 82.80 \mathrm{Pv}$

\section{Introduction}

Recently vanadium pentoxide based compounds became a subject of intensive studies. The particular physical-chemical properties of these materials allow for a wide range of practical applications such as electrochromic devices [1], cathodic electrodes for lithium batteries [2,3], humidity sensors [4], and various optical devices [5]. The interest in the vanadium compounds strongly increased during the last few years, when a phase transition in the sodium vanadium oxide bronze $\alpha^{\prime}-\mathrm{NaV}_{2} \mathrm{O}_{5}$ was observed $[6,7]$. The vanadium ions in this bronze are in the mixed valence states $\mathrm{V}^{5+}\left(3 d^{0}\right)$ and $\mathrm{V}^{4+}\left(3 d^{1}\right)$. This bronze is an inorganic material considered to exhibit the spin-Peierls transition. The last fact excites interest towards the charge ordering investigations in the vanadium oxide bronzes $\mathrm{Me}_{x} \mathrm{~V}_{2} \mathrm{O}_{5}$ (Me - alkali, alkaline earth, metal) [8].

The bronzes are usually prepared by means of solid state chemical reactions, which demand the high temperatures. As a final result, only the strong ioniccovalent bonds in the oxide materials are not destructed and take part in the formation of the compound. This method demands precise temperature regimes for ob-

\footnotetext{
* The report presented at the 36th Lithuanian National Physics Conference, 16-18 June 2005, Vilnius, Lithuania.
}

taining thermodynamically stable phases [9]. A wide range of the compounds based on the vanadium oxides may be synthesized using the hydrothermal methods [10], which require the special equipment. Only bulk or powder materials can be synthesized by both methods mentioned above. Thin films of the bronzes can be prepared by using thermal evaporation of the needed compounds [11], but this method demands high vacuum and other special equipment.

More usable method for the thin films production is the so-called soft chemistry or sol-gel synthesis, where vanadium oxide based compounds are yielded from aqueous precursors. Vanadium pentoxide gels have a layered structure, where $\mathrm{V}-\mathrm{O}$ ribbons are separated by water $[12,13]$ that permit to intercalate a wide range of various ionic and molecular species into these gels.

In this work the results of the synthesis and the characterization by using $\mathrm{X}$-ray photoelectron spectroscopy (XPS) method of vanadium oxide bronzes $\mathrm{NaV}_{2} \mathrm{O}_{5}$, $\mathrm{K}_{4.3} \mathrm{~V}_{6} \mathrm{O}_{16.2}$, and $\mathrm{Rb}_{4.4} \mathrm{~V}_{6} \mathrm{O}_{16.1}$ are presented.

\section{Experimental}

The sol-gel synthesis process for the production of the vanadium oxide bronzes can be described by the following steps: production of $\mathrm{V}_{2} \mathrm{O}_{5}$ gels, intercalation 
of the required element to the gel structure, and heating of the obtained hydrate up to the temperature ensuring the removal of all water (absorbed, zeolyte type, and chemically bonded) from the compound. For example, $\mathrm{M}_{x} \mathrm{~V}_{2} \mathrm{O}_{5}$ (Me - mono- or bi-valent ion) can be yielded from a mixing and aging process of aqueous solutions of $\mathrm{MeCl}$ (or $\left.\mathrm{MeCl}_{2}\right)-\mathrm{V}_{2} \mathrm{O}_{5}-\mathrm{H}_{2} \mathrm{O}$ at the temperature near the boiling point [14]. In this case, it is not excluded that some quantity of the chlorine will remain in the final product [15].

\subsection{Synthesis of sodium-vanadium oxide bronze}

As starting components, we have used vanadium pentoxide and $\mathrm{Na}_{2} \mathrm{SO}_{4}$ powders supplied by Aldrich. The sulphur salt was used because it is known that $\mathrm{MnSO}_{4}$ salts are good ingredients for the production of vanadium oxide bronzes by the hydrothermal method [14]. The sodium-vanadium gels were prepared by using sol-gel technology. $\mathrm{V}_{2} \mathrm{O}_{5}$ and $\mathrm{Na}_{2} \mathrm{SO}_{4}$ powders in suitable proportion were dissolved in the $10 \% \mathrm{H}_{2} \mathrm{O}_{2}$ solution at $275 \mathrm{~K}$ because this reaction is an exothermic one. Then the solution was heated up to $350 \mathrm{~K}$ for the dissociation of the peroxide compounds. Produced gels were deposited on the Ni substrate by screen printing method and dried in air at room temperature. Obtained xerogels of a dark brown color were heated up to $580 \mathrm{~K}$ in pure oxygen atmosphere ( $p=1 \mathrm{~atm})$ for one hour for the water removal from the xerogel. After this treatment, the color of the films changed from dark-brown to dark-green.

\subsection{Synthesis of potassium-and rubidium-vanadium oxide bronzes}

As initial substances the methavanadates of potassium $\left(\mathrm{KVO}_{3}\right)$ and rubidium $\left(\mathrm{RbVO}_{3}\right)$, and vanadyl sulphate $\left(\mathrm{VOSO}_{4}\right)$ were used. The potassium- and rubidium-vanadium gels were prepared by sedimentation from the solution of the corresponding alkaline metals $(\mathrm{K}$ and $\mathrm{Rb})$ methavanadates and vanadyl sulphate with the ratio $\mathrm{VOSO}_{4} / \mathrm{MVO}_{3}=0.5(\mathrm{M}=\mathrm{K}, \mathrm{Rb})$ at $\mathrm{pH}=8, T=1070 \mathrm{~K}$ and the total concentration of initial components $0.2 \mathrm{~mol} / \mathrm{l}$. The received gels were identified by the chemical analysis and X-ray methods. Produced gels were deposited on the Ni substrate by screen printing method and dried in air at room temperature. Obtained xerogels were heated up to $700 \mathrm{~K}$ in vacuum during 2 hours.
Table 1. Binding energy values $(\mathrm{eV})$ of the main XPS peaks of sodium-vanadium bronze.

\begin{tabular}{cccccc}
\hline Sample & $\mathrm{V} 2 p_{3 / 2}$ & $\mathrm{~V} 2 p_{1 / 2}$ & $\mathrm{O} 1 s$ & $\mathrm{Na} 1 s$ & $\mathrm{~S} 2 p_{3 / 2}$ \\
\hline $\mathrm{V}_{2} \mathrm{O}_{5}$ & 517.1 & 524.5 & 530.3 & - & - \\
& & & 533.2 & & \\
$\mathrm{Na}_{2} \mathrm{SO}_{4}$ & - & - & 531.6 & 1071.5 & 168.8 \\
& & & 535.9 & & \\
Xerogel & 517.1 & 524.3 & 529.9 & 1071.4 & 169.2 \\
& & & 532.0 & & \\
Bronze & 516.7 & 524.1 & 530.5 & 1072.2 & - \\
& & & 532.7 & & \\
\hline
\end{tabular}

\subsection{XPS measurements}

The chemical composition of the produced sodiumvanadium xerogel and bronze has been studied by $\mathrm{X}$-ray photoelectron spectroscopy in an Escalab MkII (VG Scientific) spectrometer equipped with a double $\mathrm{Al} / \mathrm{Mg} \mathrm{K}_{\alpha}$ (1486.6 or $1253.6 \mathrm{eV}$, respectively) excitation source, a five-channeltron detection system, and a hemispherical analyzer, which was set to $20 \mathrm{eV}$ pass energy. Photoemission data have been collected and processed by using a VGX-900 data system.

$\mathrm{X}$-ray photoelectron spectra of potassium- and rubidium-vanadium oxide bronzes were recorded using an XSAM 800 analyzer (KRATOS Analytical). The photoelectrons were excited using a nonmonochromatized $\mathrm{Al} \mathrm{K} \mathrm{K}_{\alpha}$ radiation source at $15 \mathrm{kV}$. Photoemission data have been collected and processed by using a KRATOS DS800 data system.

In both cases the binding energy (BE) scale was corrected for charging effects by assigning a value of $284.6 \mathrm{eV}$ to the C $1 s$ peak. After Shirley background substraction, nonlinear least squares curve fitting routine with a Gaussian/Lorentzian product function has been used for the analysis of XPS spectra. Relative concentrations of the elements have been calculated by a standard quantification routine, including Wagner's energy dependence of attenuation length.

\section{Results and discussion}

\subsection{Sodium-vanadium oxide bronze}

The binding energy values of the main XPS peaks for the reference compounds $\left(\mathrm{V}_{2} \mathrm{O}_{5}\right.$ and $\mathrm{Na}_{2} \mathrm{SO}_{4}$ powders), produced xerogel and bronze are reported in the Table 1.

$\mathrm{V} 2 p_{3 / 2}$ and $\mathrm{V} 2 p_{1 / 2}$ peaks in the vanadium pentoxide were observed at 517.1 and $524.5 \mathrm{eV}$, respectively. These BE values correspond to the $\mathrm{V}^{5+}$ state of vanadium and practically do not differ from those reported 
in [16]. $\mathrm{O} 1 s$ peak at $\mathrm{BE}=530.3 \mathrm{eV}$ corresponds to the $\mathrm{O}^{2-}$ ions in $\mathrm{V}_{2} \mathrm{O}_{5}$ [17]. The second, less intense XPS line of the oxygen at $533.2 \mathrm{eV}$ can be attributed to adsorbed water on the sample surface $[17,18]$ or carbonoxygen binding [19].

$\mathrm{O} 1 s$ peak spectra of the $\mathrm{Na}_{2} \mathrm{SO}_{4}$ contain two lines: more intense at $531.6 \mathrm{eV}$ and less intense at $535.9 \mathrm{eV}$. The first line can be assigned to the oxygen ions connected with sulphur [20] and the second one - with the Auger peak of sodium, which appears in the oxygen region when $\mathrm{Na}-\mathrm{O}$ compounds spectra is measured with the $\mathrm{Al} \mathrm{K} \mathrm{K}_{\alpha} \mathrm{X}$-ray source [20]. Na $1 s$ peak obtained at $\mathrm{BE}=1071.5 \mathrm{eV}$ is typical for the sodiumsulphur-oxygen compounds [21]. The binding energy of $\mathrm{S} 2 p_{3 / 2}$ peak at $168.8 \mathrm{eV}$ corresponds to the sulphuroxygen binding in $\mathrm{Na}_{2} \mathrm{SO}_{4},\left(\mathrm{SO}_{4}\right)^{-2}$ [21, 22] .

The XPS spectra of the sodium-vanadium-oxygen systems are complicated because there is the Na Auger peak $\mathrm{KL}_{1} \mathrm{~L}_{23}$ near $\mathrm{O} 1 s$ region, when the $\mathrm{Al} \mathrm{K}_{\alpha} \mathrm{X}$-ray source is used, and the same Auger peak near $\mathrm{C} 1 s$ region, when the $\operatorname{Mg~K}{ }_{\alpha}$ source is used [20]. So, the interpretation of the $\mathrm{O} 1 s$ spectra is complicated when we use the aluminium source. Therefore, for clear XPS spectra interpretation of produced xerogels and bronze films we used the magnesium X-ray source.

The $\mathrm{V} 2 p_{3 / 2}, \mathrm{~V} 2 p_{1 / 2}, \mathrm{Na} 1 s$, and $\mathrm{S} 2 p_{3 / 2}$ binding energies of the xerogel practically are equal to the similar values in the pure $\mathrm{V}_{2} \mathrm{O}_{5}$ and $\mathrm{Na}_{2} \mathrm{SO}_{4}$ powders (see Table 1). The $\mathrm{O} 1 s$ peak consists of the main line at $\mathrm{BE}=529.9 \mathrm{eV}$ and two less intense lines at 532 and $534 \mathrm{eV}$. The main part $(\mathrm{BE}=529.9 \mathrm{eV})$ of the oxygen is connected with the vanadium ions [16]. The lower amount at $\mathrm{BE}=535 \mathrm{eV}$ can be attributed to the sulphur-oxygen bindings $[20,23,24]$ and at $\mathrm{BE}=$ $534 \mathrm{eV}$ - to $\mathrm{H}_{2} \mathrm{O}$ [24].

Figure 1 reports the comparison spectra of the vanadium-oxygen region of the xerogel (as grown) and bronze (after treatment). It is clear that the main changes are in the $\mathrm{O} 1 s$ peak that can be connected with the water removal from the xerogel after the heat treatment.

The XPS spectra of the bronze consist of four peaks: $\mathrm{V} 2 p_{3 / 2}$ at $\mathrm{BE}=516.7 \mathrm{eV}, \mathrm{V} 2 p_{1 / 2}$ at $524.1 \mathrm{eV}, \mathrm{Na}$ $1 s$ at $1072.2 \mathrm{eV}$, and $\mathrm{O} 1 s$ at 530.5 and $532.7 \mathrm{eV}$ (see Table 1). The presence of sulphur in the bronze was not detected. The binding energies of the $\mathrm{V} 2 p_{3 / 2}$ and $\mathrm{V} 2 p_{1 / 2}$ peaks are shifted by $0.4 \mathrm{eV}$ to the smaller BE values in comparison with the pure vanadium pentoxide powder and xerogel. $\mathrm{BE}$ of $\mathrm{Na} 1 s$ in the bronze is higher than in the powder and xerogel by 0.7 and $0.8 \mathrm{eV}$, respectively. These facts testify that the pro-

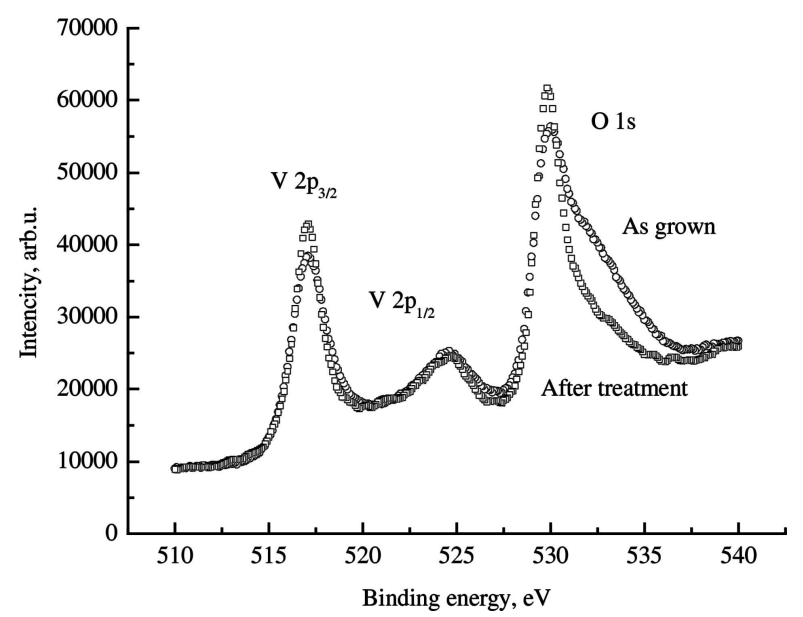

Fig. 1. Overlap spectra of $\mathrm{V}-\mathrm{O}$ region for xerogel (as grown) and bronze (after treatment) samples.

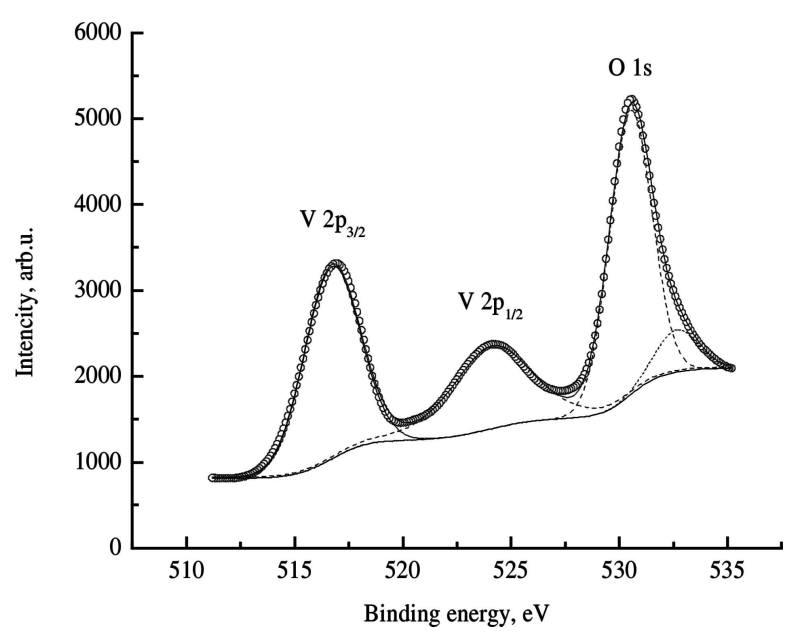

Fig. 2. Curve fitting of the $\mathrm{V} 2 p$ and $\mathrm{O} 1 s$ region for bronze sample.

duced bronze is a new chemical compound and not just a simple mixture of $\mathrm{V}_{2} \mathrm{O}_{5}$ and $\mathrm{Na}_{2} \mathrm{SO}_{4}$.

The XPS spectrum of the $\mathrm{V}-\mathrm{O}$ region of the bronze is presented in Fig. 2. The main $\mathrm{O} 1 \mathrm{~s}$ line can be attributed to the $\mathrm{O}^{2-}$ ions [17]. The less intense line at $532.7 \mathrm{eV}$ appears due to the small amount of carbon present in the sample [25] because the preparation procedure of the bronze has been carried out in air. Fitting parameters of XPS spectra and the relative chemical composition of the bronze are presented in Table 2 .

\subsection{Rubidium-vanadium oxide bronze}

Before and after the $\mathrm{Ar}^{+}$ion irradiation the $\mathrm{Rb}$ $3 d$ peaks are similar and may be deconvoluted into a poorly separated doublet with a binding energy of $\mathrm{Rb}$ $3 d_{5 / 2}$ line at $110.1 \mathrm{eV}$ and spin splitting between the $\mathrm{Rb} 3 d_{5 / 2}$ and $3 d_{3 / 2}$ lines of about $1.6 \mathrm{eV}$. Note that the $\mathrm{Rb} 3_{d 5 / 2}$ and $3 d_{3 / 2}$ peak areas ratio for both 'as grown' 
Table 2. Peak fitting parameters and relative element concentrations of sodium-vanadium bronze.

\begin{tabular}{ccccc}
\hline Peak & $\mathrm{V} 2 p_{3 / 2}$ & $\mathrm{~V} 2 p_{1 / 2}$ & $\mathrm{O} 1 s$ & $\mathrm{Na} 1 s$ \\
\hline BE, eV & 516.7 & 524.1 & 530.5 & 1072.2 \\
& & & & 532.7 \\
FWMH, eV & 3.01 & 4.34 & 2.3 & 2.34 \\
& & & & 2.3 \\
$\mathrm{~L} / \mathrm{G}^{1}, \%$ & 0 & 35 & 0 & 29 \\
Concentr. $^{2}$ & 1 & & 2.48 & 0.5 \\
\hline
\end{tabular}

${ }^{1}$ Lorentzian/Gaussian function: 0\% - Gaussian, 100\% Lorentzian.

${ }^{2}$ Concentration was calculated only for the main $\mathrm{O} 1 s$ peak at $530.5 \mathrm{eV}$.

and ' $\mathrm{Ar}^{+}$treated' samples is about 1.44, in agreement with a theoretically predicted value 1.5.

The $\mathrm{O} 1 \mathrm{~s}$ spectra of $\mathrm{Rb}_{4.1} \mathrm{~V}_{6} \mathrm{O}_{16.1}$ bronze before $\mathrm{Ar}^{+}$ion etching may be deconvoluted into three lines: the main peak at $530.3 \mathrm{eV}$ and two lower intensity peaks at 531.8 and $533.1 \mathrm{eV}$. The first one ('oxide') is assigned to $\mathrm{O}^{2-}$ ions in the bulk oxide. The second less intense line ('hydro') at $531.8 \mathrm{eV}$ appears due to a small amount of adsorbed hydroxyl groups or carbon presence in the sample because the preparation procedure of the bronze has been carried out in air, and the last one (' $\mathrm{H}_{2} \mathrm{O}$ ') at $533.1 \mathrm{eV}$ may be attributed to the absorbed water. Both before and after $\mathrm{Ar}^{+}$ion irradiation, it is impossible to fit the experimental V $2 p$ peak with only one of the synthetic doublet lines. This peak in comparison with pure $\mathrm{V}_{2} \mathrm{O}_{5}$ expands to the lower energy values, so one must introduce the additional doublets, those corresponding to the $\mathrm{V}^{4+}$ and $\mathrm{V}^{3+}$ ions. The $\mathrm{V}$ $2 p_{3 / 2}$ spectrum before $\mathrm{Ar}^{+}$treatment consists of two components with $\mathrm{V} 2 p_{3 / 2}$ binding energies 517.1 and $515.9 \mathrm{eV}$ corresponding to $\mathrm{V}^{5+}$ and $\mathrm{V}^{4+}$ species, respectively. After $\mathrm{Ar}^{+}$ion bombardment the $\mathrm{V} 2 p$ doublet is significantly broader on the side of small $\mathrm{BE}$ in comparison with the analogous spectra before sputtering. Therefore one should introduce an additional $\mathrm{V}$ $2 p$ doublet corresponding to the trivalent vanadium. $\mathrm{V}$ $2 p_{3 / 2}$ spectrum then consists of three components with $\mathrm{V} 2 p_{3 / 2}$ binding energies 517.1, 515.7, and $514.1 \mathrm{eV}$ corresponding to $\mathrm{V}^{5+}, \mathrm{V}^{4+}$, and $\mathrm{V}^{3+}$ species, respectively. The appearances of $\mathrm{V}^{3+}$ ions can be easily explained by taking into account that both $\mathrm{V}-\mathrm{O}-\mathrm{V}$ and $\mathrm{V}=\mathrm{O}$ bonds are present in the host $\mathrm{V}_{2} \mathrm{O}_{5}$ matrix. The $\mathrm{V} 2 p_{3 / 2}$ and $\mathrm{V} 2 p_{1 / 2}$ areas ratio is equal to 1.93 and 1.89 for the non-treated and $\mathrm{Ar}^{+}$etched samples, respectively, close to the theoretical value $\mathrm{V} 2 p_{3 / 2} / \mathrm{V}$ $2 p_{1 / 2}=2$.
The surface compositions of the rubidium bronze samples that have been obtained from the XPS spectra analysis, taking the vanadium stoichiometry to be 6 before and after $\mathrm{Ar}^{+}$bombardment, in conjunction with the $\mathrm{V} 2 p_{3 / 2}$ synthetic line relative intensities corresponding to various valence vanadium ions $\left(\mathrm{V}^{5+}, \mathrm{V}^{4+}\right.$, and $\mathrm{V}^{3+}$ ), are $\mathrm{Rb}_{6.69} \mathrm{~V}_{6} \mathrm{O}_{17.78}$ and $\mathrm{Rb}_{4.12} \mathrm{~V}_{6} \mathrm{O}_{15.41}$ before and after ion irradiation respectively. It is clear that rubidium segregation takes place.

\subsection{Potassium-vanadium oxide bronze}

Both before and after $\mathrm{Ar}^{+}$ion irradiation the $\mathrm{K} 2 p$ peaks are similar and may be deconvoluted into the separated doublets. The binding energies of the spin-orbit doublet $\mathrm{K} 2 p_{1 / 2}$ and $\mathrm{K} 2 p_{3 / 2}$ are 293.2 and $295.9 \mathrm{eV}$ before ion irradiation and 293.6 and $296.4 \mathrm{eV}$ after irradiation. The ratio of the integrated intensity between the $2 p_{3 / 2}$ and $2 p_{1 / 2}$ components is $\approx 1.7$ that agrees to the within the error of determination with the ratio of 2 predicted theoretically.

The presence of additional potassium compounds in the bronze is difficult to ascertain from the XPS data because of the low sensitivity of the K $2 p$ emission to the nature of a compound [17]. Some information can be gained from the $\mathrm{O} 1 \mathrm{~s}$ spectra, which was found to contain two components: one (stronger) at $530.3 \mathrm{eV}$ and the other (weaker) at $532.3 \mathrm{eV}$. A similar O $1 s$ spectrum was obtained after ion bombardment, with binding energies of 530.5 and $532.0 \mathrm{eV}$. The stronger component is attributable to the $\mathrm{O}^{2-}$ ions in oxides [20]. The weaker peak $(\sim 530 \mathrm{eV})$ seems to arise from the carbon-oxygen bonds [20]. Therefore, the observed $\mathrm{K}$ $2 p$ peaks most likely are due to the presence of $\mathrm{K}_{2} \mathrm{CO}_{3}$ on the sample surface both before and after the $\mathrm{Ar}^{+}$ion bombardment.

The $\mathrm{V} 2 p_{3 / 2}$ spectrum before $\mathrm{Ar}^{+}$treatment consists of two components with binding energies 517.3 and $516.0 \mathrm{eV}$ corresponding to $\mathrm{V}^{5+}$ and $\mathrm{V}^{4+}$ species, respectively [20]. The ratio of the integrated intensity between these two components is 10 , which implies that before the ion treatment most of the vanadium on the surface of the sample has had a valence of $5+$. The $\mathrm{Ar}^{+}$ion irradiation produces significant changes in the position and shape of the $\mathrm{V} 2 p_{3 / 2}$ peak. There are two components with the binding energies at 516.3 and $514.3 \mathrm{eV}$. These components correspond to $\mathrm{V}^{4+}$ and $\mathrm{V}^{3+}$ ions [20]. The emission characteristic of $\mathrm{V}^{5+}$ ion is missing. The ratio of the integrated intensities between the peaks corresponding to $\mathrm{V}^{4+}$ and $\mathrm{V}^{3+}$ ions is about 1.8 . 
Using the relevant sensitivity factors and taking the vanadium stoichimetry to be 6 , we evaluated the potassium and oxygen contents by comparing the $\mathrm{V} 2 p_{3 / 2}, \mathrm{~K}$ $2 p$, and $\mathrm{O} 1 s$ peak areas. The chemical formula of the bronze was $\mathrm{K}_{6.5} \mathrm{~V}_{6} \mathrm{O}_{20.3}$ and $\mathrm{K}_{3.9} \mathrm{~V}_{6} \mathrm{O}_{17.7}$ before and after $\mathrm{Ar}^{+}$ion irradiation respectively. It is clear that potassium segregation takes place.

\section{Conclusions}

The thin film of vanadium oxide bronzes $\mathrm{NaV}_{2} \mathrm{O}_{5}$, $\mathrm{K}_{4.3} \mathrm{~V}_{6} \mathrm{O}_{16.2}$, and $\mathrm{Rb}_{4.4} \mathrm{~V}_{6} \mathrm{O}_{16.1}$ were produced by solgel technology method. The XPS analysis of the starting materials, xerogel, and sodium-vanadium bronze show that the main $\mathrm{V} 2 p$ and $\mathrm{Na} 1 s$ peaks in the bronze are shifted in comparison with the other materials. That testifies that the chemical bonds of the vanadium, oxygen, and sodium in the bronze differ from similar bonds in the starting materials. Therefore, the produced bronze is not just a simple mixture of the vanadium pentoxide and sodium sulphate, but a new chemical compound. The sulphur presence was detected only in the xerogel but not in the final bronze composition.

The comparison of the chemical (bulk) and XPS (surface) analyses results of rubidium- and potassiumvanadium oxide bronzes demonstrate that the segregation of $\mathrm{Rb}$ and $\mathrm{K}$ in polyvanadate bronzes take place. After the $\mathrm{Ar}^{+}$etching the surface $\mathrm{Me} / \mathrm{V}(\mathrm{Me}=\mathrm{Rb}, \mathrm{K})$ concentrations ratio moves towards the bulk value.

The concentration of vanadium ions of reduced valence increases after $\mathrm{Ar}^{+}$bombardment of bronzes. Moreover, one needs to introduce $\mathrm{V}^{3+}$ ions to describe the $\mathrm{V} 2 p$ doublet shape after $\mathrm{Ar}^{+}$treatment. The preferential oxygen loss under $\mathrm{Ar}^{+}$bombardment is responsible for vanadium ions reduction. The valances of vanadium ions in $\mathrm{Rb}-\mathrm{V}-\mathrm{O}$ bronze after $\mathrm{Ar}^{+}$ion etching are $\mathrm{V}^{5+}, \mathrm{V}^{4+}$, and $\mathrm{V}^{3+}$. Meanwhile, in the $\mathrm{K}-\mathrm{V}-$ $\mathrm{O}$ bronze only $\mathrm{V}^{4+}$ and $\mathrm{V}^{3+}$ ions are registered. This fact testifies to less strong $\mathrm{V}-\mathrm{O}$ bonds in potassiumvanadium bronze in comparison with the rubidiumvanadium bronze. The amount of the absorbed water drastically decreases after the etching.

The final results of this work show that the simple sol-gel preparing method, which does not demand the complicated equipment, may be used for the synthesis of various vanadium pentoxide based compounds.

\section{References}

[1] J. Livage and D. Ganguli, Sol-gel electrochromic coatings and devices: A review, Sol. Energy Mater. Sol. Cells 68(3-4), 365-381 (2001).

[2] M. Miller, J. Farcy, J.P. Pereira-Ramos, E.M. Sabbar, M.E. De Ray, and J.P. Besse, A new hydrated sodium vanadium bronze as $\mathrm{Li}$ insertion compound, Solid State Ionics 112(3-4), 319-327 (1998).

[3] G. Gregoire, P. Souban, J. Farcy, J.P. Preira-Ramos, J.C. Badot, and N. Baffier, Electrochemical lithium insertion in the hexagonal cesium vanadium bronze $\mathrm{Cs}_{0.33} \mathrm{~V}_{2} \mathrm{O}_{5}$, J. Power Sources 81-82, 612-615 (1999).

[4] V. Bondarenka, S. Grebinskij, S. Mickevičius, V. Volkov, and G. Zakharova, Thin films of polyvanadium-molybdenum acid as starting materials for humidity sensors, Sensors Actuators B 28(3), 227-231 (1995)

[5] J. Livage, Optical and electrical properties of vanadium oxides synthesized from alcoxides, Coord. Chem. Rev. 190-192, 391-403 (1999).

[6] K. Kobayashi, T. Mizokawa, A. Fujimori, M. Isobe, and Y. Ueda, Angle resolved photoemission study of the spin-Peierls system $\alpha^{\prime}-\mathrm{NaV}_{2} \mathrm{O}_{5}$, J. Electron Spectrosc. Related Phenom. 92(1-3), 87-90 (1998).

[7] S. Schmidt, W. Palme, B. Lüthi, W. Weiden, R. Hauptmann, and C. Geibel, Magnetic resonance in the spinPeierls compound $\alpha^{\prime}-\mathrm{NaV}_{2} \mathrm{O}_{5}$, Phys. Rev. B 57(5), 2687-2689 (1998).

[8] M. Iton, N. Akimoto, T. Tsuchiya, H. Yamada, $\mathrm{M}$. Isobe, and $\mathrm{Y}$. Ueda, ${ }^{51} \mathrm{~V}$ NMR study of charge ordering in $\mathrm{AV}_{6} \mathrm{O}_{15}(\mathrm{~A}=\mathrm{Ca}, \mathrm{Na}$ and $\mathrm{Ag})$, Physica $\mathrm{B}$ 281-282, 606-607 (2000).

[9] V.L. Volkov, Introduction Phases Based on the Vanadium Oxides (Sverdlovsk, 1987) 179 p. [in Russian].

[10] F. Zhang, P. Zavalij, and M.S. Whittingham, Hydrothermal synthesis and electrochemistry of a manganese vanadium oxide, $\gamma-\mathrm{MnV}_{2} \mathrm{O}_{5}$, Electrochem. Commun. 1(11), 564-567 (1999).

[11] A. Česnys, V. Bondarenka, A. Oginskis, A. Latyshenka, and V. Lisauskas, Neodymiumvanadium oxide bronze thin films, J. Solid State Chem. 113(2), 438-440 (1994).

[12] J.-J. Legendre and J. Livage, Vanadium pentoxide gels: I. Structural study by electron diffraction, J. Colloid Interface Sci. 94(1), 75-83 (1983).

[13] J.-J. Legendre, P. Aldebert, N. Baffier, and J. Livage, Vanadium pentoxide gels: II. Structural study by x-ray diffraction, J. Colloid Interface Sci. 94(1), 84-89 (1983).

[14] M. Inagaki, T. Watanabe, and A. Shimizu, New process for the preparation of vanadium oxide xerogels, Solid State Ionics 86-88(2), 853-857 (1996).

[15] V. Volkov, G. Zakharova, and V. Bondarenka, Simple and Modified Xerogels of Vanadium Polyvanadates (Yekaterinburg, 2001) 194 p. [in Russian]. 
[16] G. Hopfengärtner, D. Borgman, I. Rademacher, G. Wedler, E. Hums, and G.W. Spitznagell, XPS studies of oxidic model catalysts: Internal standards and oxidation numbers, J. Electron Spectrosc. Related Phenom. 63(2), 91-116 (1993).

[17] V.I. Nefedov, D. Gati, B.E. Dzurinskii, N.P. Sergushin, and Ya.V. Salyn, Simple and coordination compounds. An X-ray photoelectron spectroscopic study of certain oxides, Russ. J. Inorg. Chem. 20, 2307-2314 (1975).

[18] A.M. Beccaria, G. Poggi, and G. Castello, Influence of passive film composition and sea water pressure on resistance to localized corrosion of some stainless steels in sea water, Br. Corrosion J. 30(4), 283-287 (1995).

[19] D. Rats, L. Vandenbulcke, R. Herbin, R. Erre, V. Serin, and J. Sevely, Characterization of ion-beam-deposited diamond-like carbon films, Thin Solid Films 270(1-2), 177-176 (1995).

[20] J.F. Mouder, W.F. Stiskle, P.E. Sobol, and K.D. Bomben, Handbook of X-ray Photoelectron
Spectroscopy (Physical Electronics, Eden Praire, Minnesota, USA, 1995) $261 \mathrm{p}$.

[21] D. Briggs and M.P. Seah, Practical Surface Analysis, Vol. 1 (Wiley, New York, 1990) 638 p.

[22] Ph. De Donato, C. Mustin, R. Benoit, and R. Erre, Spatial distribution of iron and sulphur species on the surface of pyrite, Appl. Surf. Sci. 68(1), 81-93 (1993).

[23] D. Brion, Etude par spectroscopie de photoelectrons de la degradation superficielle de $\mathrm{FeS}_{2}, \mathrm{CuFeS}_{2}, \mathrm{ZnS}$ et PbS a láie et dans léau, Appl. Surf. Sci. 5(2), 133-152 (1980).

[24] B. Stypula and J. Stoch, The characterization of passive films on chromium electrodes by XPS, Corrosion Sci. 36(12), 2159-2167 (1994).

[25] P.Y. Jouan, M.C. Peignot, Ch. Cardinald, and G. Lemperiere, Characterisation of the TiN/Si interface polyfacetted single-crystal electrodes in a chloroplatinic acid solution, Appl. Surf. Sci. 68(4), 595-603 (1993).

\title{
VANADŽIO OKSIDŲ BRONZŲ ZOLIS-GELIS SINTEZĖ IR RENTGENO FOTOELEKTRONINIAI SPEKTRAI
}

\author{
V. Bondarenka ${ }^{\text {a }}$, S. Grebinskij ${ }^{\text {a }}$, Z. Martūnas ${ }^{\text {a }}$, S. Mickevičius ${ }^{\text {a }}$, H. Tvardauskas ${ }^{\text {a }}$, S. Kačiulis $^{\text {b }}$, L. Pandolfi ${ }^{\text {, }}$, \\ V. Volkov ${ }^{c}$, N. Podvalnaia ${ }^{\mathrm{c}}$ \\ ${ }^{a}$ Puslaidininkiu fizikos institutas, Vilnius, Lietuva \\ ${ }^{\mathrm{b}}$ Nanosandaros medžiagu tyrimo institutas, Monterotondo Stac, Italija \\ ${ }^{\mathrm{b}}$ Kietojo kūno chemijos institutas, Jekaterinburgas, Rusija
}

\section{Santrauka}

Ploni vanadžio oksidų bronzų $\mathrm{NaV}_{2} \mathrm{O}_{5}, \mathrm{~K}_{4,3} \mathrm{~V}_{6} \mathrm{O}_{16,2}$ ir $\mathrm{Rb}_{4,4} \mathrm{~V}_{6} \mathrm{O}_{16,1}$ sluoksniai buvo pagaminti naudojant zolio-gelio technologiją. Sluoksnių cheminei suděčiai ir metalu jonų valentingumui nustatyti buvo naudojama Rentgeno fotoelektronu spektroskopijos (RFS) metodika. Bronzu gamybą galima suskirstyti $i$ tris etapus: 1) zolio gamyba, tirpinant reikalingas medžiagas $\left(\mathrm{V}_{2} \mathrm{O}_{5}\right.$ ir $\mathrm{Na}_{2} \mathrm{SO}_{4}$ arba rubidžio ar kalio metavanadatus kartu su vanadilo sulfatu) vandenilio perokside; 2) pagamintojo zolio kaitinimas iki $350 \mathrm{~K}$; 3) pagamintojo gelio kaitinimas iki 580-780 K, siekiant pašalinti vandens molekules iš gelio, t. y. bronzų sintezè.

$\mathrm{V}_{2} \mathrm{O}_{5}, \mathrm{Na}_{2} \mathrm{SO}_{4}, \mathrm{~V}-\mathrm{Na}-\mathrm{O}$ gelio ir bronzos RFS analizė parodè, kad pagrindinès $\mathrm{V} 2 p$ ir Na $1 s$ RFS smailès bronzoje yra pasislinku- sios, palyginus su pradinėmis medžiagomis. Tai liudija, kad cheminiai ryšiai tarp vanadžio, natrio ir deguonies bronzoje skiriasi nuo atitinkamų ryšiu pradinèse medžiagose, tai yra susintetinta bronza nèra paprastas medžiagų mišinys, o yra naujas cheminis junginys. Sieros smailè aptikta tik Na-V-O gelyje, bet jos nèra bronzoje.

Iš RFS analizès rezultatu matyti, kad rubidžio- ir kaliovanadžio oksidinėse bronzose yra stebima $\mathrm{Rb}$ ir $\mathrm{K}$ segregacija bei vandens garų ir anglies sugertis bandinių paviršiuje. Jeigu $\mathrm{Rb}-\mathrm{V}-\mathrm{O}$ bronzos paviršius labiau sugeria vandeni, tai kalio-vanadžio bronzoje dèl anglies sugerties susidaro $\mathrm{K}_{2} \mathrm{CO}_{3}$. Rubidžio-vanadžio bronzoje po bandiniu paviršiaus apšaudymo $\mathrm{Ar}^{+}$jonais šalia $\mathrm{V}^{5+}$ ir $\mathrm{V}^{4+}$ atsiranda ir $\mathrm{V}^{3+}$ jonai, o kalio-vanadžio bronzoje po apšaudymo visai išnyksta $\mathrm{V}^{5+}$ ir lieka tik $\mathrm{V}^{4+}$ ir $\mathrm{V}^{3+}$ jonai. Tai liudija apie silpnesni $\mathrm{V}-\mathrm{O}$ ryši $\mathrm{K}-\mathrm{V}-\mathrm{O}$ bronzoje. 